\title{
Banks' Risk-taking and State Ownership: Evidence from Asian Emerging Markets
}

\author{
Ai-Xin Lee ${ }^{a}$ \\ Chee-Wooi Hooy \\ Universiti Sains Malaysia
}

\begin{abstract}
This paper examines the relationship between state ownership and banks' risk-taking in nine Asian emerging markets for the period 2009 to 2017. The finding shows that state-owned banks are associated with higher risk-taking in terms of credit risk and return volatility. In addition, we investigate the effect of corporate governance (CG) mechanism with monitoring committee, board independence and gender diversity on state-owned banks' risk-taking. We find that the presence of monitoring committee on board has a reducing effect on state-owned banks' risk-taking. We further argue that independent directors help to reduce banks' risk-taking where their supervision should be robust enough even if there is huge government intervention. Nonetheless, we do not find strong evidence on the role of female directors. In a nutshell, board functions play a crucial role in monitoring and supervising banks' investment decisions to prevent excessive risk-taking from the government, which is relatively important in the context of Asian emerging markets.
\end{abstract}

Keywords: Asian emerging markets, bank risk-taking, board, corporate governance, state ownership

JEL classification: G21, G28, G32

\section{Introduction}

Rapid economic growth in the Asian markets has marked a high record during the mid-1900s showing the importance of the banking sector in fuelling economic development. This is particularly important for emerging countries where their national economic development counts heavily on soundness of the banking system. However, the emerging Asian banking sector has undergone significant changes through bank consolidations after the Asian financial crisis. The overwhelming impacts of the financial crisis show substantial vulnerability in the Asian banking system. Governmental bailouts have been blamed for banks to take excessive risks that contributed to this crisis. The level of state ownership involvement in Asia is significantly higher compared to other

a Finance Section, School of Management, Universiti Sains Malaysia, Gelugor, 11800 Penang, Malaysia. Email: aixinlee@student.usm.my

b Finance Section, School of Management, Universiti Sains Malaysia, Gelugor, 11800 Penang, Malaysia. Email: cwhooy@usm.my (Corresponding author)

* This work was supported by the USM Fellowship provided by the Institute of Postgraduate Studies, Universiti Sains Malaysia. 
regions. Government involvement in the banking sector has also increased after the financial crisis (Hossain, Jain, \& Mitra, 2013). The risk exposure faced by the Asian banking sector increased significantly when there is massive asset growth in the Asian banking market for the past decade, which leads Asia to have the world's largest banking industry. ${ }^{1}$ Among all, the growth rate of emerging Asian markets is the fastest. The increasing role of emerging markets motivates us to conduct this study. This has drawn notable attention towards Asian banking sector development. Thus, this paper sheds light on this issue by examining government ownership and risk-taking from the Asian banking sector. In this paper, we focus on nine Asian emerging markets: China, India, Indonesia, Malaysia, Pakistan, Philippines, South Korea, Taiwan and Thailand.

The extant literature shows that state-owned banks tend to perform poorer, has lower loan quality, are less efficient and less profitable. Most of the extant literature captures bank performances and efficiency and only a few gauge banks' risk-taking. The very few studies show that banks have a greater propensity to undertake risky projects if they have a direct connection to the government. The greater the government ownership, the higher the risk-taking. Based on our knowledge, very little attention has been given to Asian emerging countries, hence leaving the nexus between banks' risktaking and state ownership understudied in these markets.

This study makes two main contributions to the extant literature. First, most of the previous studies focused on developed markets, whereas studies conducted on the emerging Asian markets only examined the state ownership issue and banks' risk-taking in a single market. In other words, this study contributes by collectively addressing the issue of state ownership and banks' risk-taking in nine Asian emerging markets. Secondly, we developed three models to look at how corporate governance mechanisms affect the relationship between state ownership and banks' risk-taking through the monitoring committee, board independence and gender diversity, which were largely ignored by previous researchers. We find that state ownership in banks is crucial in determining banks' risk-taking. Besides, we also find that board functions play a crucial role in monitoring and supervising banks' investment decisions, which is relatively important in the context of Asian emerging markets.

The remainder of the paper is organised as follows. Hypotheses development is discussed in Section 2. Section 3 introduces data, variables measurement and methodology, followed by results and discussion in Section 4 and the conclusion in Section 5.

\section{Hypotheses Development}

The impact of state ownership on banks' risk-taking is still ambiguous. Most of the extant literature capture ownership structure, bank performances and efficiency - for instance, research work from Berger, Clarke, Cull, Klapper and Udell (2005), Bonin,

The data was extracted from Forbes, published in January 2018. Available at https://www.forbes.com/ sites/peterpham/2018/01/16/why-is-asia-home-to-the-worlds-biggest-banks/\#1076126b33fe 
Hasan and Wachtel (2005), Cornett, Guo, Khaksari and Tehranian (2010) and Iannotta, Nocera and Sironi (2007). Understanding the hazard of riskiness, only a few recent studies gauge risk-taking. Very little attention has been given to Asian emerging countries thus leaving the nexus between bank risk-taking and state ownership understudied in these markets.

According to prior studies, most of the findings suggest that state-owned banks have poorer performances, poorer loan quality, are less efficient and less profitable (Iannotta et al., 2007; La Porta, Lopez-de-Silanes, \& Shleifer, 2002; Shaban \& James, 2018; Zhou, Gao, \& Zhao, 2017). There is also evidence that banks might have a greater propensity to undertake risky projects if they have a direct connection to the government, and the greater the state ownership, the higher the risk-taking (BrandaoMarques, Correa, \& Sapriza, 2020; Lassoued, Sassi, \& Ben Rejeb Attia, 2016; Wang, Wong, \& Xia, 2008; Zhu \& Yang, 2016). There are a few perspectives that explain such behaviour. Firstly, moral hazard. Prior researchers explain that the presence of moral hazard induced by government protection leads to excessive risk-taking behaviour by banks. The Asian banks have been blamed for creating too many unsound loans that have triggered the Asian financial crisis in 1997. Secondly, agency problem. Prior literature claims that weak managerial incentives and resource misallocation in government bureaucracy are the results of agency problem. According to Tirole (1994), state-owned banks maximise manifold non-measurable objectives where the banks' managers have low-powered incentives. Thirdly, political view. The political view explains that the government might misallocate resources from state-owned banks for political gain (Hossain et al., 2013). Cornett et al. (2010) and La Porta et al. (2002) mentioned that political bureaucrats very often have goals that are dictated by political interests, hence they create and preserve state-owned banks as a political tool meant to fulfil their own political objectives but not maximising firm value. This can be seen from a study by Dinç (2005) who found that lending from state-owned banks increases during election years compared to private-owned banks. In addition, the finding from lannotta, Nocera and Sironi (2013) showed that during election years, governmental protection and operating risk tend to increase. Lastly, social view. The social view shows that state-owned banks tend to channel resources to develop the nation and maximise socially profitable projects as private banks fail to take social welfare into account. The social view also highlights the role of the public sector to reciprocate for market failures that leave socially profitable investments underfinanced (Sapienza, 2004; Yeyati, Micco, \& Panizza, 2004). For instance, the government funds projects through their participation in state-owned banks that would increase job creation which could not be granted by private financing (La Porta et al., 2002). In this paper, we examine whether state ownership affects banks' risk-taking in four measurements: non-performing loans (NPL) ratio, capital adequacy ratio (CAR), return volatility (STDROE - standard deviation of return on equity) and liquidity ratio (LR). Based on previous findings, we predict that state ownership is associated with higher risk-taking. Hence, we propose our first hypothesis as follows:

H1: State ownership increases banks' risk-taking. 
Corporate governance (CG) mechanisms are deemed to play a significant role in monitoring corporate activities and investment decisions made by the board. Prior studies' evidence of firms with more effective governance show a significantly lower level of risk-taking (Jiraporn, Chatjuthamard, Tong, \& Kim, 2015; OECD, 2006). The findings from studies conducted by Anderson, Mansi and Reeb (2004) and Hadani, Goranova and Khan (2011) showed that board committees play an effective monitoring role. Based on our knowledge, little attention has been given to the role of board committees in addressing state ownership issues in prior studies. The introduction of CG committee (also known as monitoring committee) to the board is tremendously important in monitoring the role play by all board members to assure that board members have adhered to corporate standards and protocols. To our knowledge, there is no literature studying the impact of CG committee in the nexus between banks' risk-taking and state ownership. Thus, we introduce CG committee in this study and investigate the monitoring role played by the CG committee in the above relationship. Hence, we propose our second hypothesis as follows:

H2: Corporate governance committee moderates the relationship between state ownership and banks' risk-taking.

Board independence is another important component in CG. The impact of independent directors studied by prior researchers is ambiguous. Advocates show that the presence of independent directors will aid in minimising the agency issue that corporates constantly faced (Klein, 2002; Rosenstein \& Wyatt, 1990). Nevertheless, others contend that independent directors often lead to inferior decisions due to their inadequate knowledge and understanding of the firm (Raheja, 2005). We assume independent directors play a significant role in addressing state ownership issues and hence propose our third hypothesis as follows:

H3: Board independence moderates the relationship between state ownership and banks' risk-taking.

The role played by female directors has grasped more attention during the past decade. Is gender diversity played by women vital in improving CG and monitoring? Previous studies showed inconclusive findings on the role of female directors on the board. Some show that female directors are more active in a monitoring role (Adams \& Ferreira, 2009). For instance, previous researchers such as Gulamhussen and Santa (2015) conducted a study in a sample of large banks from OECD countries and their results suggest that the presence of female directors has a positive impact on performance and a negative impact on risk-taking. The finding from a recent study by Nadeem, Suleman and Ahmed (2019) shows that the presence of females on the board is negatively related to firm risk. They further found a negative relationship between firm risk and profitability. A study by Khaw, Liao, Tripe and Wongchoti (2016) who investigated the relationship between gender diversity and corporate risktaking in China showed that corporate risk-taking increases when there is low gender diversity. Their finding highlights the importance of having female directors on board. However, some literature found a negative relationship between gender diversity and firm performance (Rose, 2007; Smith, Smith, \& Verner, 2006). According to a study 
by Liu, Wei and Xie (2014), they stated that female directors are more likely charged with political and social activities in the case of state-controlled firms. On the other hand, another strand of study found no evidence to prove that the presence of female directors on the board influences corporate risk (Sila, Gonzalez, \& Hagendorff, 2016). They further claimed that findings from most of the existing literature found that a negative relationship between gender diversity and risk-taking is mainly due to the unobserved between-firm factors. Thus, we can see inconclusive findings on the role of female directors from the extant literature. With this ambiguous finding, we would like to know the impact of female directors in the nexus between state ownership and banks' risk-taking in the case of Asian emerging markets. Thus, we propose our fourth hypothesis as follows:

H4: Female directors moderate the relationship between state ownership and banks' risk-taking.

\section{Data and Methodology}

\subsection{Sample Banks}

This study consists of 224 banks from nine Asian emerging markets for the period 2009 to 2017. We obtain the data from Thomson Reuters Datastream Advance 5.1 database and banks with incomplete data are excluded from our sample. In this paper, we focus on nine Asian emerging markets: China, India, Indonesia, Malaysia, Pakistan, Philippines, South Korea, Taiwan and Thailand. Following Hossain et al. (2013), the list of Asian emerging markets is collected based on the MSCI Emerging Markets Index.

\subsection{Variables Measurement}

\section{(a) State Ownership}

In this paper, we focus on banks' ownership by government and government institutions. The percentage of state ownership is obtained from Thomson Reuters Datastream database, with the code: NOSHGV under the "number of shares" section. Ultimately, the state ownership data is presented as a dummy variable. We define state ownership (SO) as " 1 " if the total percentage of state ownership in banks is equal to or more than $30 \%$ or " 0 " otherwise.

\section{(b) Risk-taking}

With carefully selecting the risk-taking variables employed in this study, we have come to four risk-taking measurements: credit risk, capital adequacy, return volatility and liquidity risk. Similar to work from Berger and DeYoung (1997), Chen, Wu, Jeon and Wang (2017), Hossain et al. (2013), Shaban and James (2018), Williams (2004), Zheng, Moudud-Ul-Huq, Rahman and Ashraf (2017) and Zhu and Yang (2016), we employ non-performing loans (NPL) ratio as the risk-taking proxy for credit risk. NPL ratio is calculated by dividing NPL by total loans. A higher NPL ratio indicates higher bank risk-taking. 
Capital adequacy is deemed as one of the important signs for banks' survival. It plays a vital role in ensuring banks have sufficient capital to keep them out of financial distress. We employ total capital ratio as a measure for capital adequacy (see Agusman, Cullen, Gasbarro, Monroe \& Zumwalt, 2014; Hossain et al., 2013; Lassoued et al., 2016; Shaban \& James, 2018; Zheng et al., 2017). A lower capital adequacy ratio (CAR) implies a higher bank risk-taking.

Return volatility is another risk measurement we employ in this study. Following Chen et al. (2017), Laeven and Levine (2009), Saunders, Strock and Travlos (1990) and Zhu and Yang (2016), we measure return volatility in the standard deviation of return on equity (STDROE) with three-consecutive-years rolling window. The higher the STDROE, the higher the return volatility of a bank, suggesting a higher risk-taking.

Liquidity risk measures in liquidity ratio (LR) is another risk measurement employed in this study. Liquid assets play a critical role in preventing banks failure during a financial crisis. The previous financial crises have shown how severely illiquidity can crystallise. Thus, it is important for banks to maintain liquidity at a healthy level. A lower LR indicates a result of higher risk-taking.

\section{(c) Moderating Variables}

We introduce three corporate governance mechanisms to look at their impact on the relationship between state ownership and banks' risk-taking. They are corporate governance (CG) committee, board independence and female directors, which were largely ignored by previous researchers. These variables are presented in percentages. We measure CG committee as the proportion of CG committee on the board. Following García-Meca, García-Sánchez and Martínez-Ferrero (2015), Liang, Xu and Jiraporn (2013), Meng, Clements and Padgett (2018) and Pathan and Faff (2013), board independence is measured as the percentage of independent directors on board. Female director is measured as the percentage of females represented on board (García-Meca et al., 2015; Liang et al., 2013; Owen \& Temesvary, 2018; Pathan \& Faff, 2013).

\section{(d) Control Variables}

Bank-level characteristics that act as control variables in this study are bank size, revenue growth and return on assets (ROA). Bank size is a prevalent control variable employed by most researchers in their studies (e.g. Agusman et al., 2014; BrandaoMarques et al., 2020; Chen, Steiner, \& Whyte, 1998; Dong, Liu, Shen, \& Sun, 2016; Lassoued et al., 2016; Saunders et al., 1990; Shaban \& James, 2018; Zheng et al., 2017). There are two perspectives regarding bank size. Some researchers pointed out that large banks tend to take higher risks with the presence of "too-big-to-fail (TBTF)" policy. Another strand of literature suggests that large banks can better diversify their risk portfolio and pursue better opportunities, hence reducing their risk-taking activities. Bank size is measured by the logarithm of banks' total assets (log total assets). The second control variable we employ in this study is revenue growth. It is calculated as the first difference of the logarithm of total operating income. This is to control the revenue growth rate as larger banks are believed to have accessibility 
to greater resources and have higher revenue growth. The third control variable in this study is return on assets (ROA). As we can see, this variable is widely used in the studies of Dong et al. (2016) and Zhu and Yang (2016). This is to control for the effect of profitability on banks' risk as banks that owned more assets will produce higher profit and face greater risk exposure.

\subsection{Model Specification}

Equation 1 below is the baseline model used in this study to examine the relationship between state ownership and banks' risk-taking:

$$
\text { Risk }_{i t}=\alpha+\beta_{1} \mathrm{SO}_{i t}+\beta_{2} \log \mathrm{TA}_{i t}+\beta_{3} \mathrm{RG}_{i t}+\beta_{4} \mathrm{ROA}_{i t}+\text { Country Dummy }+\varepsilon_{i t}
$$

where Risk $_{i t}$ is the risk measure for bank $i$ in year $t$. There are four risk measurements consisting of: NPL ratio, CAR, STDROE and LR. $\mathrm{SO}_{i t}$ is the state ownership dummy for bank $i$ in year $t$, whereas $\log \mathrm{TA}_{i t}, \mathrm{RG}_{i t}$, and $\mathrm{ROA}_{i t}$ are the control variables for bank $i$ in year $t$. The purpose of adding a country dummy is to control for unobserved country effects since this study involves multiple Asian emerging markets.

To measure corporate governance effects, we develop equations (2) to (4) to investigate the impact of CG committee, board independence and female directors in addition to the above relation in equation (1).

$$
\begin{aligned}
& \text { Risk }_{i t}=\alpha+\beta_{1} \text { CG Comm } i t+\beta_{2}(\text { CG Comm } \times S O)_{i t}+\beta_{3} \mathrm{SO}_{i t}+\beta_{4} \log \mathrm{TA}_{i t}+ \\
& \beta_{5} \mathrm{RG}_{i t}+\beta_{6} \mathrm{ROA}_{i t}+\text { Country Dummy }+\varepsilon_{i t} \\
& \mathrm{Risk}_{i t}=\alpha+\beta_{1} \operatorname{Indp}_{i t}+\beta_{2}(\operatorname{Indp} \times \mathrm{SO})_{i t}+\beta_{3} \mathrm{SO}_{i t}+\beta_{4} \log \mathrm{TA}_{i t}+\beta_{5} \mathrm{RG}_{i t}+ \\
& \beta_{6} \mathrm{ROA}_{i t}+\text { Country Dummy }+\varepsilon_{i t} \\
& \text { Risk }_{i t}=\alpha+\beta_{1} \text { Female }_{i t}+\beta_{2}(\text { Female } \times \text { SO })_{i t}+\beta_{3} \mathrm{SO}_{i t}+\beta_{4} \mathrm{Log} \mathrm{TA}_{i t}+\beta_{5} \mathrm{RG}_{i t}+ \\
& \beta_{6} \mathrm{ROA}_{i t}+\text { Country Dummy }+\varepsilon_{i t}
\end{aligned}
$$

where CG Comm it is the proportion of CG committee on board, Indp $p_{i t}$ is the percentage of independent directors on board and Female ${ }_{i t}$ is the percentage of females represented on board for bank $i$ in year $t$.

To ensure valid statistical inference, we use standard error estimation for the likely presence of within-cluster correlations as pooled OLS standard error can be biased in such conditions. Following the approaches recommended by Petersen (2009), we determine the likely presence of within-cluster correlation for the above models. Lastly, we conduct robustness test using the generalized method of moments (GMM) method to accommodate the endogeneity issue.

\subsection{Descriptive Statistics}

Table 1 provides summary statistics for all the variables used in our models. NPL, CAR, STDROE and LR are the four risk measurements which are the dependent variables used in this study. SO is the main independent variable whereas Log TA, RG and ROA are the control variables used in this study. Three moderating variables introduced in this study are CG Comm, Indp and Female. The dependent variables data value 
is winsorized at $0.5 \%$ level (0.5th and 99.5th percentiles) to remove the effects of outliers. For a comparison, we refer to the results of Zhu and Yang's (2016) study that focused solely on China's emerging market whereby the means for banks' risk-taking such as non-performing loans (NPL) and return volatility (STDROE) are 2.544 and 4.391 respectively whereas capital adequacy ratio (CAR) and liquidity ratio (LR) are 13.26 and 32.18 respectively. By focusing on a more comprehensive study of the Asian emerging markets, this study is found to have higher NPL at 3.47. On the other hand, the rest of the risk-taking measurements show substantial lower results. For instance, lower return volatility is at 3.15, while CAR and LR are at 15.05 and 86.50 respectively. The largest number of NPL in Table 1 indicates that some Asian banks have particularly high uncollectable loans, nearly $39 \%$ of the loans they lend out is in default. This signals that the behaviour of these banks (e.g. aggressively giving out loans) would potentially lead to enormous bank losses. If this happens to many banks on a large scale, it will severely affect the nations' economy.

In terms of the state ownership (SO) variable, the data ranges from 0 to 97 with an average of $13.24 \%$ compared to Vo's (2018) study where the average state ownership shareholding is about $11.09 \%$ while an average of $14.49 \%$ is found in the study from Lassoued et al. (2016). This shows that state ownership involvement in Asian emerging markets is considerably higher than the average. In order to study the impact of huge government involvement in the banking sector, the so dummy is labelled as "1" if the bank has $30 \%$ state ownership or more. This indicator shows that $18.6 \%$ of the emerging Asian banks are known as state-owned banks with huge government involvement.

Table 1. Descriptive statistics

\begin{tabular}{lrrrrr}
\hline Variable & Obs. & Mean & Std. Dev. & Min & Max \\
\hline NPL & 1,575 & 0.0347 & 0.0499 & 0.0002 & 0.3899 \\
CAR & 1,531 & 0.1505 & 0.0539 & 0.0396 & 0.5481 \\
STDROE & 1,300 & 0.0315 & 0.0429 & 0.0012 & 0.2718 \\
LR & 1,714 & 0.8650 & 0.1733 & 0.5518 & 1.202 \\
SO (percentage) & 1,787 & 13.2362 & 25.1933 & 0 & 97 \\
SO (dummy) & 1,787 & 0.1858 & 0.3890 & 0 & 1 \\
Log TA & 1,848 & 9.2749 & 1.0781 & 2.6990 & 12.0504 \\
RG & 1,484 & 0.7515 & 3.1873 & -23.3652 & 24.4391 \\
ROA & 1,563 & 1.1527 & 1.3908 & -9.91 & 5.29 \\
CG Comm & 594 & 37.8907 & 31.2824 & 15.56 & 88.72 \\
Female & 550 & 45.3886 & 27.8183 & 10.46 & 99.68 \\
Indp & 590 & 34.7192 & 22.6604 & 1.15 & 93.32 \\
\hline
\end{tabular}

Note: Obs. = Number of observations, Std. Dev. = Standard deviation, NPL = Non-performing loans ratio, CAR = Capital adequacy ratio, STDROE = Standard deviation of return on equity, LR = Liquidity ratio, $\mathrm{SO}_{\text {(percentage) }}=$ State ownership percentage, $\mathrm{SO}_{(\text {dummy) }}=$ State ownership dummy, Log TA = Logarithm of total assets, RG = Revenue growth, ROA = Return on assets, CG Comm = Percentage of corporate governance committee, Female $=$ Percentage of female directors and Indp = Percentage of independent directors on board. 
Banks' Risk-taking and State Ownership: Evidence from Asian Emerging Markets

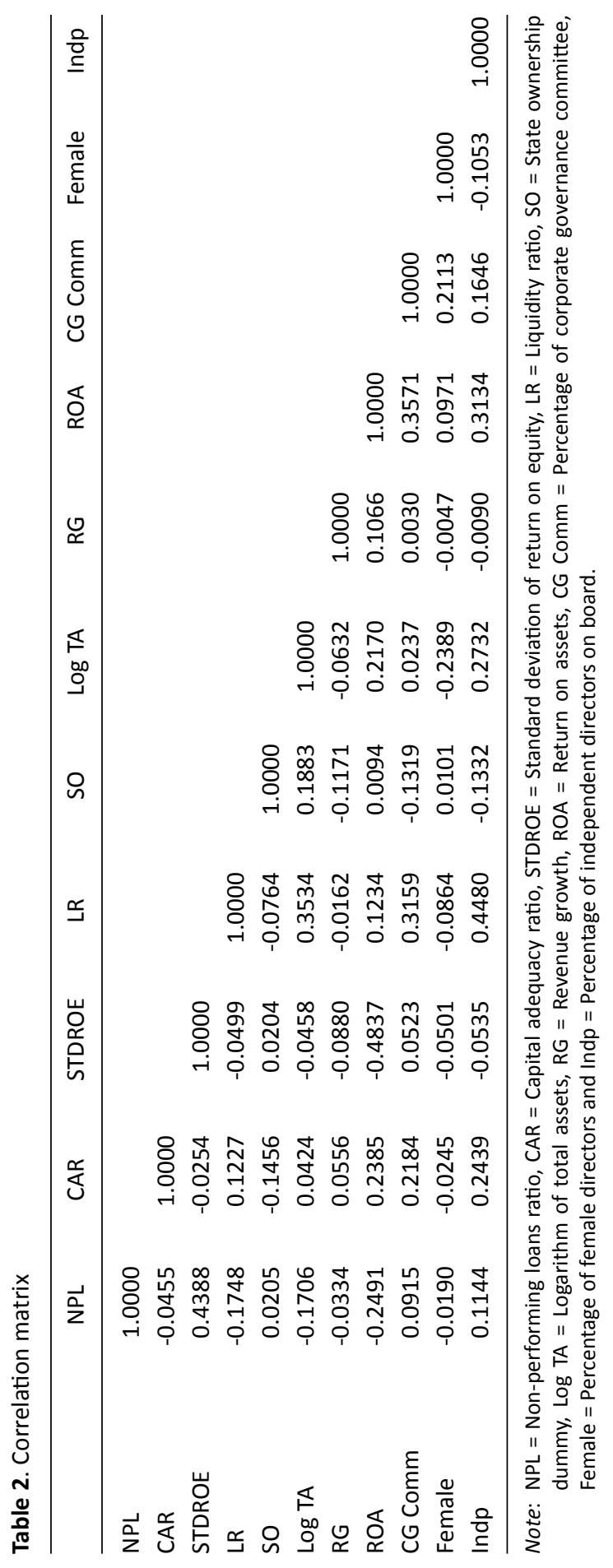


Moving on to the newly added variables in this study, we find that all banks (banks with available board information) have CG committee, female directors and independent directors on board with a prominence of board diversity and bank regulations during the past decade. On the average, banks have $37.89 \%$ of CG committee represented on board, with $45.39 \%$ represented by female directors and $34.72 \%$ represented by independent directors.

The correlation matrix is presented in Table 2. The correlation between SO and risk-taking measurements have the expected signs (positive on both NPL and STDROE, negative on CAR and LR). The correlation coefficients ranging from -0.4837 to 0.4480 signal that multicollinearity is not a concern in this study.

\section{Results and Discussion}

\subsection{Baseline Results}

Following Petersen's (2009) suggestion, we use a few standard error estimations for the likely presence of within-cluster correlations (time effect/firm effect) in this study. As we all know, OLS standard errors would be biased when the residuals in a given year are correlated across different firms (time effect), or the residuals for a given firm are correlated across years (unobserved firm effect). The result is presented in Table 3 . This table provides the comparison between the White standard error and standard errors clustered by different dimensions (for instance: time, firm and double-clustered by firm and time). Following Petersen, the White standard error served as a baseline estimate in this study. Any large differences (2 to 4 times larger) between clustered standard errors and the White standard error are due to within-cluster correlations. The first row of Table 3 shows the size and sign of coefficients for each variable. The standard errors clustered by different dimensions are reported in brackets and the asterisks denote statistical significance at $1 \%, 5 \%$ and $10 \%$ levels respectively. As we can see, comparisons of the standard errors in columns (1) to (4) for panels A to D do not differ by 2 to 4 times. This shows that within-clustered correlations are not a major issue in this study. Besides, the consistent results across the four types of robust standard errors provide a better statistical inference.

The baseline result in Table 3 shows that state ownership is associated with higher banks' risk-taking, evidenced by statistically significant positive non-performing loans (NPL) and return volatility (STDROE), plus a negative and significant coefficient on liquidity ratio (LR). Nonetheless, banks' capital adequacy ratio (CAR) is found to have no significant impact on state-owned banks from Asian emerging markets. A possible reason is that Asian banks are facing unforeseen challenges in preparing themselves for adhering to the new requirements by Basel III. The reason behind such implementation is to increase banks' capital in response to the overwhelming consequences from the global financial crisis. Facing enormous uncertainties in this implementation, the Basel Committee on Banking Supervision has repeatedly extended the full implementation from 2019 to 2022. Although CAR is found to be insignificant during the sample period in this study, this risk proxy is deemed crucial in the banking sector and should not be neglected. Overall, the significant results from most of the risk-taking proxies supported 
Table 3. Baseline regression results
(1) White
(2) Time-clustered
(3) Firm-clustered
(4) Double-clustered

\begin{tabular}{lllll}
\multicolumn{2}{l}{$\begin{array}{l}\text { Panel A: Non-performing Loans (NPL) } \\
\mathrm{N}=1111\end{array}$} & \multicolumn{4}{l}{ Adjusted $\mathrm{R}^{2}=0.4789$} & \\
\hline SO & $0.8961^{* * *}$ & $0.8961^{* * *}$ & $0.8961^{* * *}$ & $0.8961^{* * *}$ \\
& $(0.2572)$ & $(0.1942)$ & $(0.2433)$ & $(0.1754)$ \\
Log TA & -0.1843 & -0.1843 & -0.1843 & -0.1843 \\
& $(0.1575)$ & $(0.1069)$ & $(0.2395)$ & $(0.2097)$ \\
RG & -0.0381 & -0.0381 & -0.0381 & -0.0381 \\
& $(0.0458)$ & $(0.0474)$ & $(0.0565)$ & $(0.0577)$ \\
ROA & $-0.6338^{* * *}$ & $-0.6338^{* *}$ & $-0.6338^{* *}$ & $-0.6338^{* *}$ \\
& $(0.1651)$ & $(0.1880)$ & $(0.2534)$ & $(0.2689)$ \\
Constant & $5.0824^{* * *}$ & $5.0824^{* *}$ & $5.0824^{*}$ & $5.0824^{* *}$ \\
& $(1.7672)$ & $(1.6113)$ & $(2.6525)$ & $(2.5512)$
\end{tabular}

Panel B: Capital Adequacy Ratio (CAR)

\begin{tabular}{lllll}
$\mathrm{N}=1054$ & $\mathrm{R}^{2}=0.3095$ & \multicolumn{4}{l}{ Adjusted $\mathrm{R}^{2}=0.3015$} \\
\hline SO & 0.0600 & 0.0600 & 0.0600 & 0.0600 \\
& $(0.2032)$ & $(0.1845)$ & $(0.3633)$ & $(0.3532)$ \\
Log TA & $-0.7615^{* * *}$ & $-0.7615^{* * *}$ & $-0.7615^{*}$ & $-0.7615^{* *}$ \\
& $(0.2466)$ & $(0.1596)$ & $(0.3927)$ & $(0.3448)$ \\
RG & -0.0524 & -0.0524 & -0.0524 & -0.0524 \\
& $(0.0378)$ & $(0.0418)$ & $(0.0376)$ & $(0.0416)$ \\
ROA & $1.1908^{* * *}$ & $1.1908^{* * *}$ & $1.1908^{* * *}$ & $1.1908^{* * *}$ \\
& $(0.2407)$ & $(0.1537)$ & $(0.3872)$ & $(0.3400)$ \\
Constant & $21.2584^{* * *}$ & $21.2584^{* * *}$ & $21.2584^{* * *}$ & $21.2584^{* * *}$ \\
& $(2.8017)$ & $(1.6804)$ & $(4.4747)$ & $(4.2775)$
\end{tabular}

Panel C: Standard Deviation of Return on Equity (STDROE)

\begin{tabular}{lllll}
$\mathrm{N}=1015$ & $\mathrm{R}^{2}=0.0705$ & \multicolumn{3}{l}{ Adjusted $\mathrm{R}^{2}=0.0593$} \\
\hline SO & $0.4373^{* * *}$ & $0.4373^{* *}$ & $0.4373^{*}$ & $0.4373^{* *}$ \\
& $(0.1653)$ & $(0.1542)$ & $(0.2249)$ & $(0.2168)$ \\
Log TA & $-0.5035^{* * *}$ & $-0.5035^{* *}$ & $-0.5035^{* *}$ & $-0.5035^{* *}$ \\
& $(0.1476)$ & $(0.1725)$ & $(0.2282)$ & $(0.2450)$ \\
RG & -0.0438 & -0.0438 & -0.0438 & -0.0438 \\
& $(0.0368)$ & $(0.0496)$ & $(0.0353)$ & $(0.0485)$ \\
ROA & -0.1296 & -0.1296 & -0.1296 & -0.1296 \\
& $(0.1617)$ & $(0.2238)$ & $(0.1785)$ & $(0.2362)$ \\
Constant & $8.2796 * * *$ & $8.2796^{* * *}$ & $8.2796 * * *$ & $8.2796 * * *$ \\
& $(1.5855)$ & $(2.0025)$ & $(2.4715)$ & $(2.7576)$ \\
\hline
\end{tabular}


Table 3. Continued
(1) White
(2) Time-clustered
(3) Firm-clustered
(4) Double-clustered

\begin{tabular}{lllll}
\multicolumn{4}{l}{ Panel D: Liquidity } & Ratio $(\mathrm{LR})$ \\
$\mathrm{N}=1193$ & $\mathrm{R}^{2}=0.5988$ & \multicolumn{4}{l}{ Adjusted $\mathrm{R}^{2}=0.5948$} \\
\hline SO & $-2.1561^{* *}$ & $-2.1561^{* *}$ & -2.1561 & -2.1561 \\
& $(1.0371)$ & $(0.8847)$ & $(2.3020)$ & $(2.2375)$ \\
Log TA & $3.5369^{* * *}$ & $3.5369^{* * *}$ & $3.5369 * * *$ & $3.5369^{* * *}$ \\
& $(0.6122)$ & $(0.5025)$ & $(1.1711)$ & $(1.1177)$ \\
RG & -0.0029 & -0.0029 & -0.0029 & -0.0029 \\
& $(0.1227)$ & $(0.1157)$ & $(0.1245)$ & $(0.1176)$ \\
ROA & $3.2666^{* * *}$ & $3.2666^{* * *}$ & $3.2666^{* * *}$ & $3.2666^{* * *}$ \\
& $(0.6458)$ & $(0.4050)$ & $(1.3506)$ & $(1.2535)$ \\
Constant & $67.0596 * * *$ & $67.0596^{* * *}$ & $67.0596 * * *$ & $67.0596 * * *$ \\
& $(6.6317)$ & $(5.1640)$ & $(12.7954)$ & $(12.1000)$
\end{tabular}

Note: $\mathrm{NPL}=$ Non-performing loans ratio, $\mathrm{CAR}=$ Capital adequacy ratio, STDROE $=$ Standard deviation of return on equity, $\mathrm{LR}=$ Liquidity ratio, $\mathrm{SO}=$ State ownership dummy, Log $\mathrm{TA}=$ Logarithm of total assets, $\mathrm{RG}=$ Revenue growth, ROA $=$ Return on assets, White $=$ White heteroscedastic-robust. The standard errors for each dimension are reported in brackets and $* * *, * *, *$ denote the statistical significance at $1 \%$, $5 \%$ and $10 \%$ levels respectively. $\mathrm{N}$ denotes the number of observations, $\mathrm{R}^{2}$ and Adjusted $\mathrm{R}^{2}$ are the coefficients for $\mathrm{R}$-squared and adjusted $\mathrm{R}$-squared of regression model respectively.

the first hypothesis ( $\mathrm{H} 1)$ of this study, showing that state ownership increases banks' risk-taking in Asian emerging markets. This result further supports Zhu and Yang's (2016) study who found that state ownership is associated with higher risk-taking behaviour. It is worth highlighting that the results from this study provide a more comprehensive empirical evidence on the impact of state ownership on banks' risk-taking in nine Asian emerging markets whereby other prior studies who found similar findings were conducted in European countries (lannotta et al., 2013) and the Middle East and North Africa (MENA) region (Lassoued et al., 2016). This shows that government intervention has an enormous impact on the banking sector, regardless of regions. However, government involvement in the context of Asian emerging markets is deemed as an important issue where the banking sector in these markets is the dominant sector that plays a critical role to ensure long term nations' economic development. With such high risk-taking behaviour, it has important implications for the banking sector in Asian emerging markets.

The bank-level characteristics that acted as control in this study found that bank size has significant impact on all risk-taking proxies except NPL. Overall, bank size is negatively associated with risk-taking. This implies that large banks can better diversify their risk portfolio and hence reduce high risk-taking activities. Besides, bank's return on assets is also found to have a negative relationship with risk-taking. Banks that are better able to generate revenues using assets could better diversify their risk undertaking. However, the coefficient of bank's revenue growth is insignificant in relation 
to risk-taking. This finding is surprising and enlightens that in the context of Asian emerging markets, bank's revenue growth does not have a relationship with risk-taking.

\subsection{Further Analyses}

To provide further understanding on the nexus between state ownership and banks' risk-taking, this paper examines the effect of corporate governance mechanisms on banks' risk-taking with the presence of monitoring committee (percentage of CG committee on board), board independence (percentage of independent directors on board) and gender diversity (percentage of female directors represented on board) in the following sub-sections.

\section{(a) Corporate Governance (CG) Committee}

The effect of CG committee in the nexus between state ownership and banks' risktaking is reported in Table 4. Results in Table 4 show that two proxies of banks' risk-taking out of four evidenced that the presence of CG committee in state-owned banks helps to reduce banks' risk-taking, which is indicated by a statistically negative significant return volatility (STDROE) and positive significant liquidity ratio (LR). Despite

Table 4. Effect of corporate governance (CG) committee

\begin{tabular}{lcccc}
\hline & NPL & CAR & STDROE & LR \\
\hline SO & $0.5916^{* *}$ & 0.2032 & $0.4612^{*}$ & 0.7650 \\
& $(0.0160)$ & $(0.5321)$ & $(0.0907)$ & $(0.6679)$ \\
CG Comm & 0.0014 & 0.0009 & $0.0072^{*}$ & 0.0293 \\
& $(0.6890)$ & $(0.8401)$ & $(0.0555)$ & $(0.2131)$ \\
SOCG & 0.0005 & -0.0085 & $-0.0125^{* *}$ & $0.0744^{*}$ \\
& $(0.9352)$ & $(0.2781)$ & $(0.0484)$ & $(0.0709)$ \\
Log TA & $0.3007^{*}$ & $0.4377^{* *}$ & -0.0828 & $-1.8189^{*}$ \\
& $(0.0735)$ & $(0.0318)$ & $(0.5990)$ & $(0.0828)$ \\
RG & -0.0478 & -0.0152 & -0.0356 & $-0.4615^{* *}$ \\
& $(0.1375)$ & $(0.7263)$ & $(0.3580)$ & $(0.0459)$ \\
ROA & -0.2083 & $1.2899^{* * *}$ & -0.1695 & $5.3635^{* * *}$ \\
& $(0.1417)$ & $(0.0000)$ & $(0.3211)$ & $(0.0000)$ \\
Constant & -1.8121 & $7.1168^{* * *}$ & 2.2369 & $89.8592^{* * *}$ \\
& $(0.2816)$ & $(0.0005)$ & $(0.1573)$ & $(0.0000)$ \\
\hline $\mathrm{N}$ & 457 & 426 & 427 & 495 \\
r2_a & 0.3770 & 0.5148 & 0.0461 & 0.5897 \\
r2 & 0.3961 & 0.5308 & 0.0775 & 0.6013 \\
\hline
\end{tabular}

Note: $\mathrm{NPL}=$ Non-performing loans ratio, $\mathrm{CAR}=$ Capital adequacy ratio, $\mathrm{STDROE}=$ Standard deviation of return on equity, $L R=$ Liquidity ratio, $S O=$ State ownership dummy, CG Comm = Percentage of corporate governance committee on board, SOCG = Interaction of state ownership dummy and CG committee on board, Log $\mathrm{TA}=$ Logarithm of total assets, $\mathrm{RG}=$ Revenue growth, ROA = Return on assets. $\mathrm{N}$ denotes the number of observations, $r 2$ and r2_a are the coefficients for R-squared and adjusted R-squared of the regression model respectively. $* * *, * *, *$ denote statistical significance at $1 \%, 5 \%$ and $10 \%$ levels respectively. 
no strong evidence to support the effect of CG committee in Asian state-owned banks, results from Table 4 show that the CG committee plays a tremendously important role in monitoring bank activities and reducing their risk undertaking. The baseline results in Table 3 show that state-owned banks are associated with higher risk-taking in terms of credit risk, return volatility and liquidity risk. However, the significant results (lower STDROE and higher LR) prove that monitoring from CG committee leads to risk reduction in state-owned banks.

Taken together, these results enlighten that the presence of CG committee on board is important and should not be neglected. This is because the monitoring role played by the CG committee in helping to assure the board members have adhered to corporate standards and protocols is deemed as an important act to reduce risk-taking behaviour in Asian state-owned banks.

\section{(b) Independent Directors}

Hypothesis 3, which tests the effect of independent directors for the baseline model is examined and reported in Table 5. The results in Table 5 show that the presence of independent directors in Asian state-owned banks varied. Their presence is associated with significant positive NPL and LR at $99 \%$ and $95 \%$ confidence level respectively.

Table 5. Effect of independent directors

\begin{tabular}{llccc}
\hline & NPL & CAR & STDROE & LR \\
\hline SO & -0.2976 & -0.0634 & 0.2885 & -1.3556 \\
& $(0.3762)$ & $(0.8858)$ & $(0.4449)$ & $(0.5841)$ \\
Indp & $-0.0215^{* * *}$ & $0.0145^{*}$ & -0.0086 & -0.0507 \\
& $(0.0002)$ & $(0.0518)$ & $(0.1586)$ & $(0.2087)$ \\
SOIndp & $0.0276^{* * *}$ & 0.0030 & -0.0072 & $0.1320^{* *}$ \\
& $(0.0030)$ & $(0.7928)$ & $(0.4416)$ & $(0.0341)$ \\
Log TA & $0.2884^{*}$ & $0.4368^{* *}$ & -0.0125 & $-2.1570^{* *}$ \\
& $(0.0795)$ & $(0.0304)$ & $(0.9361)$ & $(0.0400)$ \\
RG & -0.0520 & -0.0150 & -0.0340 & $-0.4900^{* *}$ \\
& $(0.1008)$ & $(0.7291)$ & $(0.3803)$ & $(0.0350)$ \\
ROA & -0.1309 & $1.1329^{* * *}$ & 0.0383 & $5.5562^{* * *}$ \\
& $(0.3606)$ & $(0.0000)$ & $(0.8266)$ & $(0.0000)$ \\
Constant & -1.1458 & $6.9910^{* * *}$ & 1.6381 & $95.3712^{* * *}$ \\
& $(0.4898)$ & $(0.0007)$ & $(0.3014)$ & $(0.0000)$ \\
\hline $\mathrm{N}$ & 455 & 424 & 425 & 493 \\
r2_a & 0.3967 & 0.5176 & 0.0447 & 0.5857 \\
r2 & 0.4153 & 0.5335 & 0.0763 & 0.5975 \\
\hline
\end{tabular}

Note: $\mathrm{NPL}=$ Non-performing loans ratio, $\mathrm{CAR}=$ Capital adequacy ratio, $\mathrm{STDROE}=$ Standard deviation of return on equity, $\mathrm{LR}=$ Liquidity ratio, $\mathrm{SO}=$ State ownership dummy, Indp = Percentage of independent directors represented on board, SOIndp = Interaction of state ownership dummy and independent directors on board, Log TA = Logarithm of total assets, RG = Revenue growth, ROA = Return on assets. $\mathrm{N}$ denotes the number of observations, $\mathrm{r} 2$ and $\mathrm{r} 2$ _a are the coefficients for R-squared and adjusted $\mathrm{R}$-squared of the regression model respectively. $* * *, * *, *$ denote statistical significance at $1 \%, 5 \%$ and $10 \%$ levels respectively. 
Although the effect of independent directors is mixed, we claim that the presence of independent directors in state-owned banks helps to reduce banks' risk-taking. By examining the role of independent directors alone, the sign shows that they are providing good supervision by reducing credit risk and improving banks' capital. Their presence further strengthens the liquidity placement in banks even if there is huge government ownership (more than $30 \%$ ) intervention. This can be seen from the greater coefficient of 0.1320 for LR. Nonetheless, these directors induced greater credit risk when there is huge government intervention. A possible explanation is that the government helps to provide funding for projects that would increase job creation in line with the social view that could not be granted by private financing. This action can be seen as advantageous from the social point of view, however aggressively giving out loans has a drawback on the nation's long-term economic development. As mentioned in Section 3.4, Asian banks have significantly higher default loans. In this scenario, Asian banks should reduce involvement in activities that would give an impact on credit risk. Therefore, the supervision from independent directors should be robust enough besides improving banks' liquidity placement. They play a vital role in monitoring banks' activities and investment decisions to avoid excessive risk-taking behaviour from the government.

\section{(c) Female Directors}

Table 6 reports the effect of female directors on the relationship between state ownership and banks' risk-taking, which tests the fourth hypothesis of the study. The presence of female directors in state-owned banks is significant at 0.0141 and -0.0868 for CAR and LR respectively, at $90 \%$ confidence level. A possible explanation is that female directors in state-owned banks might have been focusing and helping the banks to position themselves to meet the latest Basel III capital requirements whereby full implementation will commence in year 2022. However, while preparing for long-term capital requirements, ease of liquidity for the short-term has been neglected. Overall, results from Table 6 show mixed findings and do not provide strong evidence on the role of female directors in state-owned banks. This finding further supports Sila et al. (2016) who found no evidence on the presence of female directors and corporate risk. Although the participation of females has become more presiding lately, their role in the Asian banking sectors particularly emerging markets is yet to fully flourish.

\subsection{Robustness Check}

Our main findings may be subjected to unobserved time-invariant individual effects and endogeneity issues. Hence, we address these potential issues by introducing a few well-known alternatives in corporate finance research such as GMM, two-stage least squares (2SLS) and Fama-MacBeth (FM) regression. The 2SLS is an extension of the OLS approach. In $2 \mathrm{SLS}$, an external instrumental variable is used to create a new variable and replace the problematic variable whereas the instrumental variable used in GMM is more straightforward by using lagged levels of existing variables. Nonetheless, Fama and French (1988) contended that the FM approach is rectified for cross-sectional correlation and does not accurately account for time series autocorrelation over long 
Table 6. Effect of female directors

\begin{tabular}{lcccc}
\hline & NPL & CAR & STDROE & LR \\
\hline SO & $0.9164^{* * *}$ & -0.7023 & 0.1130 & $7.2973^{* * *}$ \\
& $(0.0040)$ & $(0.1194)$ & $(0.7683)$ & $(0.0034)$ \\
Female & -0.0012 & $-0.0093^{* *}$ & -0.0020 & -0.0128 \\
& $(0.6790)$ & $(0.0260)$ & $(0.5452)$ & $(0.5650)$ \\
SOFemale & -0.0064 & $0.0141^{*}$ & 0.0032 & $-0.0868^{*}$ \\
& $(0.2560)$ & $(0.0896)$ & $(0.6435)$ & $(0.0544)$ \\
Log TA & 0.1026 & $1.1431^{* * *}$ & -0.2135 & $-5.4138^{* * *}$ \\
& $(0.5901)$ & $(0.0000)$ & $(0.3325)$ & $(0.0004)$ \\
RG & $-0.0603^{*}$ & -0.0307 & -0.0283 & $-0.5461^{* *}$ \\
& $(0.0531)$ & $(0.4821)$ & $(0.4981)$ & $(0.0265)$ \\
ROA & $-0.2784^{* *}$ & $1.5806^{* * *}$ & -0.1272 & $5.1119^{* * *}$ \\
& $(0.0428)$ & $(0.0000)$ & $(0.4784)$ & $(0.0000)$ \\
Constant & 0.3528 & 0.2704 & $3.6714 *$ & $127.2684^{* * *}$ \\
& $(0.8541)$ & $(0.9190)$ & $(0.0999)$ & $(0.0000)$ \\
\hline $\mathrm{N}$ & 444 & 402 & 397 & 462 \\
2_a & 0.4335 & 0.5441 & 0.0546 & 0.5727 \\
r2 & 0.4514 & 0.5601 & 0.0880 & 0.5857 \\
\hline
\end{tabular}

Note: $\mathrm{NPL}=$ Non-performing loans ratio, $\mathrm{CAR}=$ Capital adequacy ratio, STDROE $=$ Standard deviation of return on equity, $L R=$ Liquidity ratio, $S O=$ State ownership dummy, Female = Percentage of female directors represented on board, SOFemale $=$ Interaction of state ownership dummy and female directors on board, Log TA = Logarithm of total assets, RG = Revenue growth, ROA = Return on assets. $\mathrm{N}$ denotes the number of observations, $r 2$ and r2_a are the coefficients for R-squared and adjusted R-squared of the regression model respectively. $* * *, * *, *$ denote statistical significance at $1 \%, 5 \%$ and $10 \%$ levels respectively.

horizons. Hence, the FM estimator might not be suitable to be employed in long periods of corporate finance settings. Therefore, the GMM estimator is recognised as more efficient than the 2SLS and FM as it allows for heteroscedasticity, serial correlation and non-normal distribution.

Numerous empirical studies in corporate finance often employed dynamic panel data models to study the dynamics of corporate financial variables. Following the recommendation from Roodman (2009), this paper employs system GMM estimator to capture the importance of the dynamic nature of state ownership and bank risktaking variables, and to address possible endogeneity concerns of some other variables. This suggests that state ownership could influence banks' risk-taking in various ways, and vice versa. Prior studies suggest that ownership is endogenous as it is influenced by banks' level of risk-taking (Demsetz \& Lehn, 1985; Gugler \& Weigand, 2003; Himmelberg, Hubbard, \& Palia, 1999; Pindado \& Torre, 2004; Srairi, 2013). A recent study by Zheng et al. (2017) showed a non-linear relationship for risk and ownership structure. As argued by Uddin (2016), the government maintains its ownership in banks for the sake of political and social objectives. The government, as the most influential shareholder in a bank, will ultimately reflect their interests on banks' risk-taking. For 
instance, if the government is more conservative and emphasises on people's welfare, they will not undertake strategies that induce high uncertainties. On the contrary, if the government practices bribery and political corruption, these behaviours increase their risk undertaking which eventually cause the entire society and economy to suffer. Besides that, the government also affects the bank's risk-taking decision which will have an impact on the bank's performances and national growth. For instance, a government agency would invest in banks that have outstanding performance and hence reflect their ownership in banks. Therefore, GMM is expected to solve the likelihood of reverse causality issues mentioned.

The system GMM estimator improves efficiency by the inclusion of the lags of instrumental variables and it is claimed that the two-step estimation in system GMM is more efficient than one-step estimation (Jha, 2019; Roodman, 2009). Hence, we rewrite the baseline model equation (1) by including instrumental lag variables into our model. The two-step system GMM result is presented in Table 7. The GMM result shows that the majority of the findings are consistent with the baseline result. The first row in Table 7 shows that state ownership is associated with higher credit risk and higher return volatility, indicated by higher non-performing loans (NPL) ratio and higher

Table 7. Robustness check using generalized method of moments (GMM)

\begin{tabular}{lllll}
\hline & NPL & CAR & STDROE & LR \\
\hline SO & $1.5797^{* * *}$ & -0.0093 & $1.4587 * * *$ & -0.2015 \\
& $(0.0000)$ & $(0.9533)$ & $(0.0000)$ & $(0.7358)$ \\
Log TA & $-0.7732 * * *$ & -0.1501 & $-1.2628 * * *$ & $-0.4995^{*}$ \\
RG & $(0.0000)$ & $(0.1053)$ & $(0.0000)$ & $(0.0871)$ \\
& $-0.3535^{* * *}$ & $0.0239 *$ & $-0.2660 * * *$ & $0.3522 * * *$ \\
ROA & $(0.0000)$ & $(0.0868)$ & $(0.0000)$ & $(0.0000)$ \\
& $-1.4580 * * *$ & $1.2138 * * *$ & $-0.4096 * * *$ & $0.6649 * * *$ \\
Constant & $(0.0000)$ & $(0.0000)$ & $(0.0000)$ & $(0.0026)$ \\
& $8.9970 * * *$ & 0.3238 & $12.2686 * * *$ & 0.2979 \\
AR(1) test statistic & $(0.0000)$ & $(0.6909)$ & $(0.0000)$ & $(0.8932)$ \\
& $-1.96 *$ & $-3.37 * * *$ & $-2.27 * *$ & $-7.06 * * *$ \\
AR(2) test statistic & $(0.0506)$ & $(0.0008)$ & $(0.0235)$ & $(0.0000)$ \\
& -0.86 & 1.15 & -2.11 & 1.22 \\
Sargan test of & $(0.3916)$ & $(0.2492)$ & $(0.3470)$ & $(0.2228)$ \\
over-identification & $464.00 * * *$ & $351.51 * * *$ & $444.77 * * *$ & $218.15 * * *$ \\
Hansen test of & $(0.0000)$ & $(0.0000)$ & $(0.0000)$ & $(0.0140)$ \\
over-identification & 128.10 & 128.44 & 110.96 & 118.94 \\
\hline N & $(0.2896)$ & $(0.2826)$ & $(0.2785)$ & $(0.5103)$ \\
\hline
\end{tabular}

Note: $\mathrm{NPL}=$ Non-performing loans ratio, $\mathrm{CAR}=$ Capital adequacy ratio, STDROE $=$ Standard deviation of return on equity, $L R=$ Liquidity ratio, $S O=$ State ownership dummy, Log $T A=$ Logarithm of total assets, $R G=$ Revenue growth, $\mathrm{ROA}=$ Return on assets. $\mathrm{N}$ denotes the number of observations. $* * *, * *, *$ denote statistical significance at $1 \%, 5 \%$ and $10 \%$ levels respectively. 
standard deviation of return on equity (STDROE). The other two risk-taking measurements on capital adequacy ratio (CAR) and liquidity ratio (LR) show the expected sign but are not significant.

The bank-level characteristics that act as control variables become more significant after the inclusion of lag variables in the model. The second row of Table 7 shows that bank size is negatively related to risk-taking. This suggests that large banks can better diversify their risk portfolio and pursue better opportunities, hence reducing their risk-taking activities. Moving to the third row, the coefficient and sign for revenue growth (RG) are consistent across all four risk-taking measurements and become more significant (significantly negative on both NPL and STDROE and significantly positive on both CAR and LR). This enlightens that banks that have higher revenue growth tend to have lower risk-taking. Similarly, the coefficient and sign for return on assets (ROA) are also consistent across all four risk-taking measurements. It has a significant negative coefficient on NPL and STDROE; but significant positive coefficient on both CAR and LR at $99 \%$ confidence level. These values suggest that banks that are better able to generate revenues using assets can better diversify their risk undertaking.

\section{Conclusion and Implication}

The objective of this study is to examine the effect of state ownership on banks' risktaking with a sample of banks in the Asian emerging markets. The statistically robust results provide evidence that state-owned banks are associated with higher risktaking in terms of credit risk and return volatility. In addition, this paper finds that CG committee (monitoring committee) plays a vital role in monitoring and has a reducing effect on state-owned banks' risk-taking. We further argue that independent directors help to reduce banks' risk-taking where their supervision should be robust enough even if there is huge government intervention. Nonetheless, we do not find strong evidence on the role of female directors in the context of state-owned banks in Asian emerging markets.

This paper has important implications for the banking sector in Asian emerging markets. Our finding shows that the government tends to undertake higher risk-taking. Such behaviour will hamper national economic development especially in emerging markets that heavily counts on the soundness of the banking system. In addition, the finding from corporate governance mechanisms proved that an effective monitoring role played by the CG committee is vital in reducing state-owned banks' risk-taking. Moreover, independent directors can further strengthen their stand in providing a better monitoring role to prevent excessive risk-taking by the government. They play a crucial role in monitoring and supervising overall banks' activities and investment decisions. This is particularly important in the context of state-owned banks in Asian emerging markets.

\section{References}

Adams, R.B., \& Ferreira, D. (2009). Women in the boardroom and their impact on governance and performance. Journal of Financial Economics, 94(2), 291-309. https://doi.org/10.1016/j. jfineco.2008.10.007 
Agusman, A., Cullen, G.S., Gasbarro, D., Monroe, G.S., \& Zumwalt, J.K. (2014). Government intervention, bank ownership and risk-taking during the Indonesian financial crisis. Pacific-Basin Finance Journal, 30(C), 114-131. https://doi.org/10.1016/j.pacfin.2014.07.003

Anderson, R.C., Mansi, S.A., \& Reeb, D.M. (2004). Board characteristics, accounting report integrity, and the cost of debt. Journal of Accounting and Economics, 37(3), 315-342. https:// doi.org/10.1016/j.jacceco.2004.01.004

Berger, A.N., Clarke, G.R.G., Cull, R., Klapper, L., \& Udell, G.F. (2005). Corporate governance and bank performance: A joint analysis of the static, selection, and dynamic effects of domestic, foreign, and state ownership. Journal of Banking \& Finance, 29(8-9), 2179-2221. https://doi. org/10.1016/j.jbankfin.2005.03.013

Berger, A.N., \& DeYoung, R. (1997). Problem loans and cost efficiency in commercial banks. Journal of Banking \& Finance, 21(6), 849-870. https://doi.org/10.1016/S0378-4266(97)00003-4

Bonin, J.P., Hasan, I., \& Wachtel, P. (2005). Bank performance, efficiency and ownership in transition countries. Journal of Banking \& Finance, 29(1), 31-53. https://doi.org/10.1016/j. jbankfin.2004.06.015

Brandao-Marques, L., Correa, R., \& Sapriza, H. (2020). Government support, regulation, and risk taking in the banking sector. Journal of Banking \& Finance, 112, article 105284. https://doi. org/10.1016/j.jbankfin.2018.01.008

Chen, C.R., Steiner, T.L., \& Whyte, A.M. (1998). Risk-taking behavior and management ownership in depository institutions. Journal of Financial Research, 21(1), 1-16.

Chen, M., Wu, J., Jeon, B.N., \& Wang, R. (2017). Do foreign banks take more risk? Evidence from emerging economies. Journal of Banking \& Finance, 82, 20-39. https://doi.org/10.1016/j. jbankfin.2017.05.004

Cornett, M.M., Guo, L., Khaksari, S., \& Tehranian, H. (2010). The impact of state ownership on performance differences in privately-owned versus state-owned banks: An international comparison. Journal of Financial Intermediation, 19(1), 74-94. https://doi.org/10.1016/ j.jfi.2008.09.005

Demsetz, H., \& Lehn, K. (1985). The structure of corporate ownership: Causes and consequences. Journal of Political Economy, 93(6), 1155-1177. https://doi.org/10.1086/261354

Dinç, I.S. (2005). Politicians and banks: Political influences on government-owned banks in emerging markets. Journal of Financial Economics, 77(2), 453-479. https://doi.org/10.1016/j. jfineco.2004.06.011

Dong, Y., Liu, Z., Shen, Z., \& Sun, Q. (2016). Does state ownership really matter in determining access to bank loans? Evidence from China's partial privatization. Pacific-Basin Finance Journal, 4O(A), 73-85. https://doi.org/10.1016/j.pacfin.2016.09.001

Fama, E.F., \& French, K.R. (1988). Permanent and temporary components of stock prices. Journal of Political Economy, 96(2), 246-273.

García-Meca, E., García-Sánchez, I.-M., \& Martínez-Ferrero, J. (2015). Board diversity and its effects on bank performance: An international analysis. Journal of Banking \& Finance, 53, 202-214. https://doi.org/10.1016/j.jbankfin.2014.12.002

Gugler, K., \& Weigand, J. (2003). Is ownership really endogenous? Applied Economics Letters, 10(8), 483-486. https://doi.org/10.1080/1350485032000095357

Gulamhussen, M.A., \& Santa, S.F. (2015). Female directors in bank boardrooms and their influence on performance and risk-taking. Global Finance Journal, 28(C), 10-23. https://doi. org/10.1016/j.gfj.2015.11.002

Hadani, M., Goranova, M.L., \& Khan, R.H. (2011). Institutional investors, shareholder activism, and earnings management. Journal of Business Research, 64(12), 1352-1360. https://doi. org/10.1016/j.jbusres.2010.12.004 
Himmelberg, C.P., Hubbard, R.G., \& Palia, D. (1999). Understanding the determinants of managerial ownership and the link between ownership and performance. Journal of Financial Economics, 53(3), 353-384. https://doi.org/10.1016/S0304-405X(99)00025-2

Hossain, M., Jain, P.K., \& Mitra, S. (2013). State ownership and bank equity in the AsiaPacific region. Pacific-Basin Finance Journal, 21(1), 914-931. https://doi.org/10.1016/j. pacfin.2012.06.004

Iannotta, G., Nocera, G., \& Sironi, A. (2007). Ownership structure, risk and performance in the European banking industry. Journal of Banking \& Finance, 31(7), 2127-2149. https://doi. org/10.1016/j.jbankfin.2006.07.013

lannotta, G., Nocera, G., \& Sironi, A. (2013). The impact of government ownership on bank risk. Journal of Financial Intermediation, 22(2), 152-176. https://doi.org/10.1016/j.jfi.2012.11.002

Jha, C.K. (2019). Financial reforms and corruption: Evidence using GMM estimation. International Review of Economics \& Finance, 62(C), 66-78. https://doi.org/10.1016/j.iref.2019.03.003

Jiraporn, P., Chatjuthamard, P., Tong, S., \& Kim, Y.S. (2015). Does corporate governance influence corporate risk-taking? Evidence from the Institutional Shareholders Services (ISS). Finance Research Letters, 13, 105-112. https://doi.org/10.1016/j.frl.2015.02.007

Khaw, K.L.-H., Liao, J., Tripe, D., \& Wongchoti, U. (2016). Gender diversity, state control, and corporate risk-taking: Evidence from China. Pacific-Basin Finance Journal, 39(C), 141-158. https://doi.org/10.1016/j.pacfin.2016.06.002

Klein, A. (2002). Audit committee, board of director characteristics, and earnings management. Journal of Accounting and Economics, 33(3), 375-400. https://doi.org/10.1016/S01654101(02)00059-9

La Porta, R., Lopez-de-Silanes, F., \& Shleifer, A. (2002). Government ownership of banks. Journal of Finance, 57(1), 265-301. https://doi.org/10.1111/1540-6261.00422

Laeven, L., \& Levine, R. (2009). Bank governance, regulation, and risk taking. Journal of Financial Economics, 93(2), 259-275. https://doi.org/10.1016/j.jfineco.2008.09.003

Lassoued, N., Sassi, H., \& Ben Rejeb Attia, M. (2016). The impact of state and foreign ownership on banking risk: Evidence from the MENA countries. Research in International Business and Finance, 36, 167-178. https://doi.org/10.1016/j.ribaf.2015.09.014

Liang, Q., Xu, P., \& Jiraporn, P. (2013). Board characteristics and Chinese bank performance. Journal of Banking \& Finance, 37(8), 2953-2968. https://doi.org/10.1016/j.jbankfin. 2013.04.018

Liu, Y., Wei, Z., \& Xie, F. (2014). Do women directors improve firm performance in China? Journal of Corporate Finance, 28(C), 169-184. https://doi.org/10.1016/j.jcorpfin.2013.11.016

Meng, Y., Clements, M.P., \& Padgett, C. (2018). Independent directors, information costs and foreign ownership in Chinese companies. Journal of International Financial Markets, Institutions and Money, 53, 139-157. https://doi.org/10.1016/j.intfin.2017.09.016

Nadeem, M., Suleman, T., \& Ahmed, A. (2019). Women on boards, firm risk and the profitability nexus: Does gender diversity moderate the risk and return relationship? International Review of Economics \& Finance, 64, 427-442. https://doi.org/10.1016/j.iref.2019.08.007

OECD. (2006). Policy brief on corporate governance of banks in Asia. Paris, France: Author. Retrieved from https://www.oecd.org/daf/ca/corporategovernanceprinciples/37180641.pdf

Owen, A.L., \& Temesvary, J. (2018). The performance effects of gender diversity on bank boards. Journal of Banking \& Finance, 90, 50-63. https://doi.org/10.1016/j.jbankfin.2018.02.015

Pathan, S., \& Faff, R. (2013). Does board structure in banks really affect their performance? Journal of Banking \& Finance, 37(5), 1573-1589. https://doi.org/10.1016/j.jbankfin. 2012.12.016

Petersen, M.A. (2009). Estimating standard errors in finance panel data sets: Comparing approaches. Review of Financial Studies, 22(1), 435-480. https://doi.org/10.1093/rfs/hhn053 
Pindado, J., \& Torre, C.D.L. (2004). Why is ownership endogenous? Applied Economics Letters, 11(14), 901-904. https://doi.org/10.1080/1350485042000267003

Raheja, C.G. (2005). Determinants of board size and composition: A theory of corporate boards. Journal of Financial and Quantitative Analysis, 40(2), 283-306. https://doi.org/10.2139/ ssrn. 522542

Roodman, D. (2009). How to do xtabond2: An introduction to difference and system GMM in Stata. Stata Journal, 9(1), 86-136. https://doi.org/10.1177/1536867X0900900106

Rose, C. (2007). Does female board representation influence firm performance? The Danish evidence. Corporate Governance: An International Review, 15(2), 404-413. https://doi. org/10.1111/j.1467-8683.2007.00570.x

Rosenstein, S., \& Wyatt, J.G. (1990). Outside directors, board independence, and shareholder wealth. Journal of Financial Economics, 26(2), 175-191. https://doi.org/10.1016/0304405X(90)90002-H

Sapienza, P. (2004). The effects of government ownership on bank lending. Journal of Financial Economics, 72(2), 357-384. https://doi.org/10.1016/j.jfineco.2002.10.002

Saunders, A., Strock, E., \& Travlos, N.G. (1990). Ownership structure, deregulation, and bank risk taking. Journal of Finance, 45(2), 643-654. https://doi.org/10.1111/j.1540-6261.1990. tb03709.x

Shaban, M., \& James, G.A. (2018). The effects of ownership change on bank performance and risk exposure: Evidence from Indonesia. Journal of Banking \& Finance, 88, 483-497. https://doi. org/10.1016/j.jbankfin.2017.02.002

Sila, V., Gonzalez, A., \& Hagendorff, J. (2016). Women on board: Does boardroom gender diversity affect firm risk? Journal of Corporate Finance, 36, 26-53. https://doi.org/10.1016/j. jcorpfin.2015.10.003

Smith, N., Smith, V., \& Verner, M. (2006). Do women in top management affect firm performance? A panel study of 2,500 Danish firms. International Journal of Productivity and Performance Management, 55(7), 569-593. https://doi.org/10.1108/17410400610702160

Srairi, S. (2013). Ownership structure and risk-taking behaviour in conventional and Islamic banks: Evidence for MENA countries. Borsa Istanbul Review, 13(4), 115-127. https://doi. org/10.1016/j.bir.2013.10.010

Tirole, J. (1994) . The internal organization of government. Oxford Economic Papers, 46(1), 1-29.

Uddin, M.H. (2016). Effect of government share ownership on corporate risk taking: Case of the United Arab Emirates. Research in International Business and Finance, 36, 322-339. https:// doi.org/10.1016/j.ribaf.2015.09.033

Vo, X.V. (2018). Do firms with state ownership in transitional economies take more risk? Evidence from Vietnam. Research in International Business and Finance, 46, 251-256. https://doi. org/10.1016/j.ribaf.2018.03.002

Wang, Q., Wong, T.J., \& Xia, L. (2008). State ownership, the institutional environment, and auditor choice: Evidence from China. Journal of Accounting and Economics, 46(1), 112-134. https:// doi.org/10.1016/j.jacceco.2008.04.001

Williams, J. (2004). Determining management behaviour in European banking. Journal of Banking \& Finance, 28(10), 2427-2460. https://doi.org/10.1016/j.jbankfin.2003.09.010

Yeyati, E.L., Micco, A., \& Panizza, U. (2004). Should the government be in the banking business? The role of state-owned and development banks (Inter-American Development Bank Working Paper No. 517). Washington, DC: Inter-American Development Bank, Research Department. Retrieved from https://www.econstor.eu/bitstream/10419/88042/1/idb-wp_517.pdf

Zheng, C., Moudud-UI-Huq, S., Rahman, M.M., \& Ashraf, B.N. (2017). Does the ownership structure matter for banks' capital regulation and risk-taking behavior? Empirical evidence from a developing country. Research in International Business and Finance, 42, 404-421. https://doi.org/10.1016/j.ribaf.2017.07.035 
Zhou, K.Z., Gao, G.Y., \& Zhao, H. (2017). State ownership and firm innovation in China: An integrated view of institutional and efficiency logics. Administrative Science Quarterly, 62(2), 375-404. https://doi.org/10.1177/0001839216674457

Zhu, W., \& Yang, J. (2016). State ownership, cross-border acquisition, and risk-taking: Evidence from China's banking industry. Journal of Banking \& Finance, 71, 133-153. https://doi. org/10.1016/j.jbankfin.2016.05.004 